\title{
Resveratrol in Alzheimer's disease: a review of pathophysiology and therapeutic potential
}

\author{
Resveratrol na doença de Alzheimer: uma revisão sobre fisiopatologia e potencial terapêutico \\ Júlia Canto e SOUSA', Ana Carolina Fauaze SANTANA', Gabriela Jesus Prado MAGALHÃES ${ }^{1}$
}

\begin{abstract}
Background:Alzheimer's disease (AD) is a neurodegenerative disorder characterized by progressive and irreversible loss of cognitive function. The presence of senile plaques is one of the pathological markers of the disease and is associated with the onset of neuroinflammatory mechanisms. The exact pathophysiology of AD has not been completely understood, and there are no curative therapies yet. Resveratrol (3,5,4'-trihydroxy-trans-stilbene) is a polyphenol that is noted for its antioxidant and anti-inflammatory properties. Objective: To review the role of resveratrol in the pathophysiological aspects of AD. Methods: This study carried out a literature review using PubMed/Medline, Virtual Health Library (VHL), Web of Sciences, SCOPUS and the Cochrane Library databases. Original research articles, describing both in vitro and in vivo experiments, published between 2008 and 2018, were included. Results: We identified 667 articles, of which 619 were excluded because they were repeated or did not follow the inclusion criteria. The present study includes the remaining 48 articles. Discussion: Resveratrol demonstrates beneficial and protective effects in AD models and seems to provide a promising therapeutic alternative. Conclusion: Although resveratrol appears to mitigate some pathophysiological aspects of AD, further studies are needed to prove the safety and efficacy of this compound in humans.
\end{abstract}

Keywords: amyloid; sirtuin 1; antioxidants; polyphenols; nutraceuticals.

\section{RESUMO}

Introdução: A doença de Alzheimer (DA) é neurodegenerativa e caracterizada por perda progressiva e irreversível da função cognitiva. A presença de placas senis é um dos marcadores patológicos da doença e está associada ao aparecimento de mecanismos neuroinflamatórios. A fisiopatologia exata da DA ainda não é completamente compreendida, e ainda não existem terapias curativas. O resveratrol (3,5,4'-trihidroxi-trans-estilbeno) é um polifenol conhecido por suas propriedades antioxidantes e anti-inflamatórias. Objetivo: Revisar o papel do resveratrol nos aspectos fisiopatológicos da DA. Métodos: Este estudo realizou uma revisão narrativa da literatura a partir das bases de dados PubMed/Medline, Biblioteca Virtual em Saúde (BVS), Web of Science, SCOPUS e Cochrane Library. Foram incluídos artigos originais, realizados in vitro e in vivo, publicados entre 2008 e 2018. Resultados: Foram identificados 667 artigos, dos quais 619 foram excluídos por estarem repetidos ou não se enquadrarem nos critérios de inclusão. 0 presente estudo inclui os 48 artigos restantes. Discussão: O resveratrol demonstra efeitos benéficos e protetores em modelos de DA, bem como parece fornecer uma alternativa terapêutica promissora. Conclusão: Embora o resveratrol pareça atenuar alguns aspectos fisiopatológicos da DA, são necessários mais estudos para comprovar a segurança e a eficácia deste composto em seres humanos.

Palavras-chave: amiloide; sirtuína 1; antioxidantes; polifenóis; nutracêuticos.

The aging process physiology is associated with cognitive function loss, impacting on a decrease in abilities such as learning, memory and intellectual activity, due to the brain function degeneration ${ }^{1}$.

Alzheimer's disease $(\mathrm{AD})$ is the most common form of neurodegenerative disorder, affecting the cortex and hippocampus $^{2,3}$, and leads to a progressive cognitive function worsening in the individual, resulting in impairments in speech, word and object recognition, as well as the inability to perform voluntary movements ${ }^{4}$. $\mathrm{AD}$ mainly affects the elderly and is the fifth cause of death in this population ${ }^{5}$.

Such disease is particularly characterized by the presence of two pathological markers: neurofibrillary tangles, resulting from hyperphosphorylation and abnormal deposition of tau protein, and presence of senile plaques, which are formed by the deposition of $\beta$-amyloid peptides $(\mathrm{A} \beta)^{6}$.

\footnotetext{
1Universidade Salvador, Escola de Ciências da Saúde, Departamento de Nutrição, Salvador BA, Brazil.

Júlia Canto e SOUSA (D) https://orcid.org/0000-0002-5592-0061; Ana Carolina Fauaze SANTANA (D) https://orcid.org/0000-0002-2610-9640; Gabriela Jesus Prado MAGALHÃES (D) https://orcid.org/0000-0003-2194-9517

Correspondence: Júlia Canto e Sousa; Avenida Luís Viana, 3.146/3.100,41720-200, Pituaçu, Salvador BA, Brazil; E-mail: juliacantonut@gmail.com Conflict of interest: There is no conflict of interest to declare.
}

Received on September 04, 2019; Received in its final form on December 24, 2019; Accepted on January 17, 2020. 
Although there is currently no cure for $\mathrm{AD}^{7}$, adopting a healthier lifestyle has been associated with a reduction of cognitive impairment and of dementia risk. Strategies include caloric restriction, physical exercise, and ingestion of antioxidant foods, which are associated with neuroprotective mechanisms ${ }^{1}$.

Resveratrol (3,5,4'-trihydroxy-trans-stilbene) is a polyphenol produced by several plants, and the main food sources are grapes and red wine ${ }^{8}$. This compound has gained notoriety in scientific circles, due to its biological and pharmacological properties $^{9}$. It seems to exert beneficial effects in vitro and in vivo, although the precise mechanisms are still poorly understood ${ }^{10}$.

Turner et al. observed that resveratrol supplementation in patients with mild to moderate dementia was safe and well tolerated. Despite the fast metabolism, resveratrol and its main metabolites were identified in the plasma and cerebrospinal fluid (CSF) of the individuals, demonstrating their ability to cross the blood-brain barrier (BBB) and stabilize $A \beta$ levels ${ }^{11}$.

Given the impact of $\mathrm{AD}$ on the quality and life expectancy of the affected individuals and the lack of information regarding effective therapeutic alternatives, the present study aims to review the literature regarding the role of resveratrol in pathophysiological aspects of $\mathrm{AD}$, especially the aggregation of $\mathrm{A} \beta$ peptides and consequent triggering of neuroinflammatory processes.

\section{METHODS}

A literature review of published articles was carried out between February and November of 2018 using the search terms "Alzheimer's disease", "resveratrol”, and “amyloid” on the PubMed/ Medline, Virtual Health Library (VHL), Web of Science, SCOPUS, and Cochrane Library databases. Original experimental articles that addressed the performance of resveratrol on the pathophysiological factors of $\mathrm{AD}$, especially neuroinflammation and $\mathrm{A} \beta$ peptide aggregation, both in vitro and in vivo, published in English, were selected. We excluded articles that were literature reviews or that did not particularly focus on the study objective.

\section{RESULTS}

We identified 667 articles, of which 619 were excluded because they did not fit the inclusion criteria. The remaining 48 articles have been included in this study. Figure 1 outlines our study selection process in a flowchart.

\section{DISCUSSION}

\section{Alzheimer's disease: clinical and pathophysiological aspects}

The pathophysiology of $\mathrm{AD}$ has not been completely understood yet. However, histopathological characteristics are the focus of attention, especially the deposition of $A \beta$, which appears to trigger the inflammation and oxidative stress that leads to neurodegeneration ${ }^{3}$. As a result, most of the $\mathrm{AD}$ studies in recent years have been conducted based on the amyloid cascade hypothesis, which advocates that $\mathrm{A} \beta$ deposition is the primary event in disease pathogenesis ${ }^{12,13,14}$.

$\beta$-amyloid proteins are peptides consisting of 36 to 43 amino acids that have been derived from the sequential cleavage of the amyloid precursor protein (APP $)^{15}$. $\beta$-secretase/BACE1 aspartic protease and $\gamma$-secretase proteolytic complex cleave APP to produce A $\beta$ peptides ${ }^{16,17}$. An imbalance between the production and clearance of these peptides enhances their aggregation and triggers the formation of senile plaques ${ }^{6}$. However, the reason for excessive $A \beta$ in the brain is not known ${ }^{18}$.

The deposition of $\mathrm{A} \beta$ peptides in brain regions related to memory and learning, such as the frontal cortex and hippocampus, is considered an early event in disease progression ${ }^{19}$. Even though there are several products of APP cleavage, the aggregation of peptides of 40-42 amino acids in length are important in the $\mathrm{AD}$ development ${ }^{20}$, especially those terminated at amino acid $42(\mathrm{~A} \beta 42)^{12}$.

Neuroinflammation is another important characteristic feature in $\mathrm{AD}$, which is manifested through the microglia proliferation and activation ${ }^{21}$. Microglia are the resident macrophages of the brain and form dense clusters around $\beta$-amyloid plaques. These cells function as tracers for damage to the central nervous system and detect injuries to the cerebral parenchyma ${ }^{20}$.

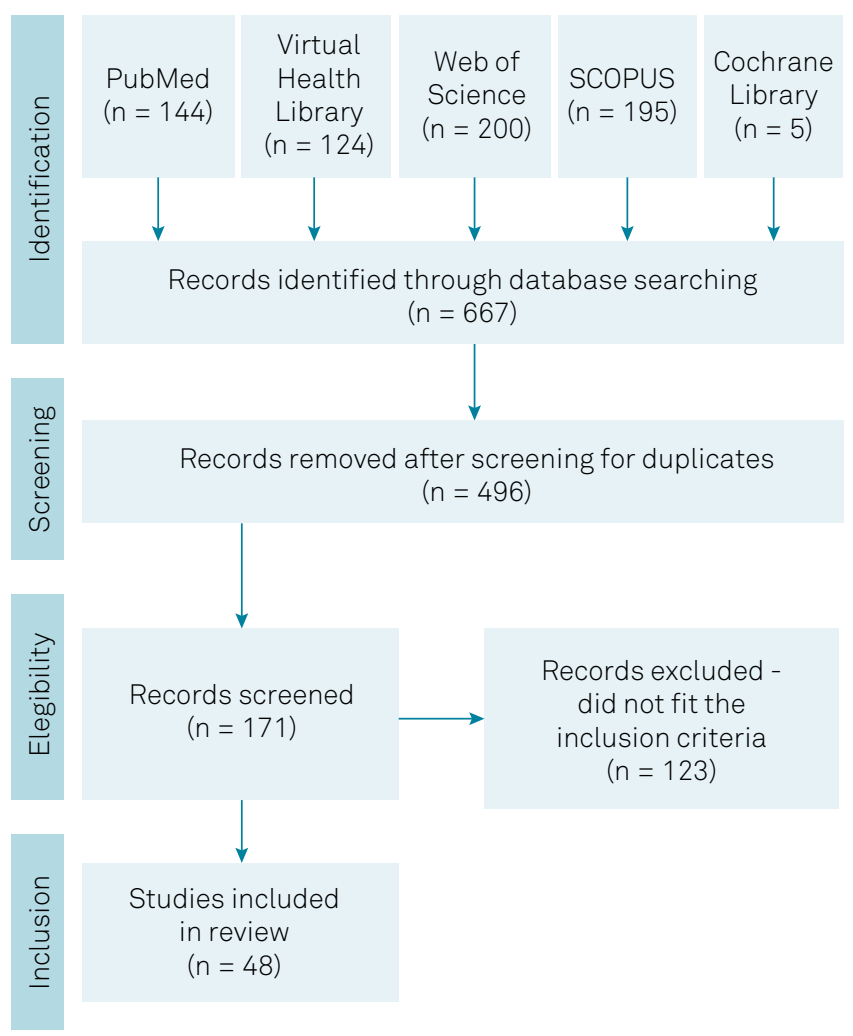

Figure 1. Flow diagram of study selection. 
Upon detection of damage or immune stimulus in the brain, such as that caused by $A \beta$ peptides, microglia are activated and produce proinflammatory mediators, for instance, tumor necrosis factor (TNF), interleukin-1 $\beta$ (IL-1 $\beta$ ) and nitric oxide (NO) in response to it. The accumulation of these mediators contributes to neuronal damage and disease progression ${ }^{8}$. In addition, the NF- $\mathrm{KB}$ transcription factor is considered the primary regulator of the inflammatory response in $\mathrm{AD}^{20}$.

Free radicals also seem to play a key role in brain aging $^{15}$. Several studies have found an association between $\mathrm{A} \beta$-promoted cytotoxicity and oxidative stress as a result from an imbalance between the production and removal of reactive oxygen species $(\mathrm{ROS})^{17}$.

High levels of ROS may lead to the destruction of proteins, nucleic acids and lipid peroxidation, as well as impairments in the cell membrane integrity, reduction of mitochondrial membrane potential, and an increase in plasma membrane permeability to calcium ions. This increase in reactive species, due to the reduction of antioxidant defenses, is responsible for the neurodegeneration mediated by oxidative stress ${ }^{15}$.

Currently, the drugs available for treating $\mathrm{AD}$ are not completely effective and do not alter the disease progression ${ }^{13,22,23}$. It is, therefore, critical that new therapies aimed to prevent and manage this chronic and debilitating disease be developed ${ }^{24}$.

\section{Resveratrol}

Several foods and natural products, whose chemical components demonstrate interesting pharmacological properties, have been suggested as $\mathrm{AD}$ modifying agents ${ }^{10,17}$.

Polyphenols are natural compounds derived from plants, fruits and vegetables, whose biological properties have demonstrated several beneficial effects, such as antioxidant and anti-inflammatory activities ${ }^{23}$.

Resveratrol is a non-flavonoid polyphenol ${ }^{8}$ part of the stilbene family ${ }^{23}$, which can be found in grape skin and seeds, blackberries, peanuts, and vegetables ${ }^{25}$. Red wine is therefore also a good source of resveratrol, to which the potential beneficial health effects of this beverage has been attributed ${ }^{26}$.

The biological activity inherent to resveratrol has been discussed in literature for some time, such as its antioxidant, anti-inflammatory, anticarcinogenic and anti-aging effects in different organisms. More recently, the neuroprotective potential has also started to gain interest ${ }^{2}$.

\section{Effects of resveratrol on Alzheimer's disease}

\section{Disaggregation of $A \beta$-peptides}

Since $\beta$-amyloid aggregates have been strongly associated with $\mathrm{AD}$ pathogenesis, compounds that promote the inhibition of formation and destruction of preformed aggregates and attenuate $\mathrm{A} \beta$-promoted cytotoxicity may provide an important therapeutic strategy for $\mathrm{AD}$, as demonstrated by Feng et al. Although it does not prevent oligomerization of
$A \beta 42$, resveratrol seems to stabilize preformed oligomers and to attenuate oligomer toxicity ${ }^{26}$. This outcome is similar to the findings of Ladiwala et al. and Rushworth et al., in which resveratrol was also able to selectively remodel $A \beta$ oligomers to non-toxic structures ${ }^{27,28}$.

Aromatic interactions between compounds and $A \beta$ peptides are a determining factor in the inhibition of fibrillar formation and reduction of amyloid toxicity ${ }^{26}$. As verified also by Ge et al., resveratrol was able to bind directly to the amyloid structure $^{12}$. Fu et al. have also noted that resveratrol binds to the N-terminus (residue 5-20) of the A $\beta 42$ monomer and caps the height of oligomers, resulting in a reduction in toxicity $^{29}$. Other studies have also shown a reduction in amyloid aggregation, both at a concentration of $50^{30}$ and $100 \mu \mathrm{M}^{31}$.

In CHO-APPswe cells, administration of resveratrol $(100 \mu \mathrm{M})$ reduced amyloid burden, APP expression, and cleavage $^{32}$. Karuppagounder et al. reported that $300 \mathrm{mg} / \mathrm{kg} /$ day of resveratrol supplementation also decreased the amount and amyloid burden in brain regions of mice, but this difference was not statistically significant ${ }^{33}$.

Similarly, Varamini et al. found that resveratrol supplementation of $174 \mathrm{mg} / \mathrm{kg} /$ day in AßPP/PS1 mice showed no differences in amyloid burden or levels of tau phosphorylation. However, resveratrol was able to increase the levels of proteins involved in neuroprotection processes ${ }^{34}$. In $\mathrm{AD} /$ $\mathrm{TTR}+$ /- mice, the same amount of resveratrol supplementation increased transthyretin levels (TTR) and stabilized TTR tetramers, which bind more strongly to $\mathrm{A} \beta$ peptides, preventing their aggregation ${ }^{35}$.

In addition, in A PPP/PS1 mice, the supplementation of lower doses (100 ppm by weight) of resveratrol, or its synthetic analog LD55, significantly decreased the density of $\mathrm{A} \beta$ plaques in different brain regions, including the cortex and hippocampus ${ }^{20}$. The effects of resveratrol on $A \beta$-peptide aggregation are summarized in Table 1.

\section{Neuroinflammation}

Activated microglia seem to be an important target of the neuroprotective activity of resveratrol, resulting in the reduction of pro-inflammatory factors ${ }^{36}$. Regarding the findings of Solberg et al., microglial activation was physically associated with amyloid plaques. In addition, resveratrol and its analogue reduced microglia activation, both of which are inhibitors of the NF- $\kappa B$ pathway ${ }^{20}$.

It is noteworthy that the hippocampus, which is the brain region mostly affected by neuroinflammation, presented a greater reduction in the density of activated microglia in response to the compounds. The LD55 analogue has no hydroxyl group, which is present in the resveratrol structure; therefore, it does not have antioxidant properties. However, the compound showed the same efficacy and anti-inflammatory potential of resveratrol, suggesting that the effect is independent of antioxidant function and a result of its ability to inhibit the NF- $\mathrm{KB}$ signaling pathway in activated microgliia ${ }^{20}$. 
In rat astrocytes (RA) and microglia N9 cell lines, resveratrol administration also promoted anti-inflammatory effects by inhibiting NF- $\mathrm{KB}$ signaling and release of inflammatory cytokines at different concentrations $(5,12.5$, and $25 \mu \mathrm{M}$ in RA cell line and 10, 20, and $40 \mu \mathrm{M}$ in $\mathrm{N} 9$ cell line). In this experiment, cytotoxicity was found when the concentration of resveratrol was higher than $50 \mu \mathrm{M}$ in the RA cell line and higher than $80 \mu \mathrm{M}$ in the $\mathrm{N} 9$ microglia cell line ${ }^{37}$.

In another experiment, administration of resveratrol in BV-2 and RAW 264.7 cell lines and supplementation of $350 \mathrm{mg} / \mathrm{kg} /$ day in APP/PS1 mice also inhibited A $\beta$-mediated microglia activation and lipopolysaccharide (LPS)stimulated activation of NF- $\mathrm{KB}$, reducing the expression of its target genes, such as TNF and IL-6 $6^{38}$. In BV-2 cells activated by $\beta$-amyloid oligomers, resveratrol $(1,3,10$ or $30 \mu \mathrm{M})$ reduced the production of reactive species and inhibited the production of inflammatory mediators, among them NO in a dose-dependent manner ${ }^{8}$. Overproduction of NO has been associated with $\mathrm{AD}$, resulting in damage to DNA and the mitochondrial structure ${ }^{39}$.

In HEK-AbPP cells treated with a $\gamma$-secretase inhibitor (LY450139), additional treatment with resveratrol $(0.5 \mu \mathrm{M})$ ceased most of the neurotoxicity and pro-apoptotic effects, promoting maximum neuroprotection. The authors have also discussed the importance of associating different neuroprotective agents, such as antioxidants (resveratrol) with $\mathrm{AD}$-specific drugs ${ }^{40}$.

Neuroprotective effects were also observed with the injection of resveratrol in rats $(100 \mu \mathrm{M} / 5 \mu \mathrm{L})$, which reduced amyloid accumulation, protected animals against neuronal death, increased antioxidant enzyme heme oxygenase-1 (HO-1) expression, and suppressed lipid peroxidation in the hippocampus. In addition, resveratrol improved spatial memory in the animals, which had been impaired by $A \beta^{39}$.

Table 1. Effects of resveratrol on $A \beta$-peptide aggregation.

\begin{tabular}{|c|c|c|c|c|}
\hline Compound & Sample & Administration & Results & Reference \\
\hline $\begin{array}{l}\text { Resveratrol, } \\
\text { catechins, } \\
\text { curcumin and } \\
\text { ginkgolides }\end{array}$ & A $\beta 42$ medium & $\begin{array}{l}\text { Added in medium } \\
(2,10 \text { and } 100 \mu \mathrm{M})\end{array}$ & $\begin{array}{l}\text { Resveratrol inhibited fibrillar formation } \\
\text { and aggregation of } A \beta 42 \text {. It did not prevent } \\
\text { oligomerization, but it stabilized them, } \\
\text { and less toxic oligomers were formed. }\end{array}$ & Feng et al. ${ }^{26}$ \\
\hline Resveratrol & Tg19959 mice & $\begin{array}{l}\text { Supplementation } \\
\text { of } 300 \mathrm{mg} / \mathrm{kg} / \mathrm{day} \\
\text { for } 45 \text { days }\end{array}$ & $\begin{array}{c}\text { Reduced the amount and burden of } \\
\text { amyloid plaques in the brain, but it was } \\
\text { not statistically significant. }\end{array}$ & Karuppagounder et al..$^{33}$ \\
\hline Resveratrol & $\begin{array}{l}\text { A } \beta \text { structures } \\
\text { samples }\end{array}$ & Added in medium $(20 \mu \mathrm{M})$ & $\begin{array}{l}\text { Remodeled A } \mathrm{\beta} \text { oligomers into non-toxic } \\
\text { oligomers and monomers. }\end{array}$ & Ladiwala et al. ${ }^{27}$ \\
\hline Resveratrol & $\begin{array}{l}\text { Solution of } A \beta \\
\text { and fibrillar } A \beta\end{array}$ & Added in medium $(50 \mu \mathrm{M})$ & $\begin{array}{l}\text { Bound directly to the monomeric } \\
\text { and fibrillar amyloid structure. }\end{array}$ & Ge et al. ${ }^{12}$ \\
\hline Resveratrol & Aß42 medium & Added in medium $(50 \mu \mathrm{M})$ & Reduced amyloid aggregation. & Hung et al. ${ }^{30}$ \\
\hline Resveratrol & $\begin{array}{l}\text { A } \beta P P / P S 1 \\
\text { mice }\end{array}$ & $\begin{array}{l}\text { Supplementation } \\
\text { of } 174 \mathrm{mg} / \mathrm{kg} / \mathrm{day} \\
\text { for } 16 \text { weeks }\end{array}$ & $\begin{array}{c}\text { There was no difference in amyloid burden } \\
\text { or tau phosphorylation levels. It increased } \\
\text { levels of proteins involved in neuroprotective } \\
\text { processes (GSK3 and Transthyretin) }\end{array}$ & Varamini et al. ${ }^{34}$ \\
\hline $\begin{array}{l}\text { Resveratrol and } \\
\text { EGCG }\end{array}$ & A $\beta 42$ medium & $\begin{array}{l}\text { Added in medium } \\
\text { (10:1 molar excess of } \\
\text { resveratrol and } 4: 1 \text { molar } \\
\text { excess of EGCG) }\end{array}$ & $\begin{array}{c}\text { Resveratrol and EGCG re-modelled fibrillar } \\
\text { conformation of } A \beta \text { oligomers } \\
\text { into nonfibrillar oligomers and they } \\
\text { were no longer cytotoxic }\end{array}$ & Rushworth et al. ${ }^{28}$ \\
\hline $\begin{array}{l}\text { Resveratrol and } \\
\text { curcumin }\end{array}$ & Aß42 medium & $\begin{array}{l}\text { Added in medium } \\
(1: 1 \text { molar ratio })\end{array}$ & $\begin{array}{l}\text { Resveratrol bound to the } \mathrm{N} \text {-terminus } \\
\text { (residue } 5 \text {-20) of the A } 42 \text { monomer and } \\
\text { caps the height of the oligomers, } \\
\text { resulting in a reduction in toxicity }\end{array}$ & Fu et al. ${ }^{29}$ \\
\hline $\begin{array}{l}\text { Resveratrol and } \\
\text { LD55 }\end{array}$ & $\begin{array}{l}\text { A } \beta P P / P S 1 \\
\text { mice }\end{array}$ & $\begin{array}{l}\text { Supplementation of } \\
100 \text { ppm for } 12 \text { months }\end{array}$ & $\begin{array}{l}\text { Decreased } A \beta \text { plaque density in brain } \\
\text { regions, such as cortex and hippocampus }\end{array}$ & Solberg et al ${ }^{2} 0$ \\
\hline Resveratrol & $\begin{array}{c}\text { Transgenic C. } \\
\text { elegans strain } \\
\text { CL2006, } \\
\text { expressing } \\
\text { A } \beta 1-42\end{array}$ & $\begin{array}{l}\text { Added in medium } \\
\qquad(100 \mu \mathrm{M})\end{array}$ & Reduced amyloid aggregation & Regitz et al. ${ }^{31}$ \\
\hline Resveratrol & $\begin{array}{l}\text { AD/TTR } \\
+/- \text { mice }\end{array}$ & $\begin{array}{l}\text { Supplementation of } 174 \\
\mathrm{mg} / \mathrm{kg} / \text { day to } \\
\text { 5- to 8-month-old }\end{array}$ & $\begin{array}{c}\text { Increased TTR levels and stabilized TTR } \\
\text { tetramers, preventing aggregation } \\
\text { of A } \beta \text { peptides }\end{array}$ & Santos et al. ${ }^{35}$ \\
\hline Resveratrol & $\begin{array}{l}\text { CHO-APPswe } \\
\text { cell culture }\end{array}$ & $\begin{array}{l}\text { Added in medium } \\
\qquad(100 \mu \mathrm{M})\end{array}$ & $\begin{array}{l}\text { Reduced amyloid burden, expression } \\
\text { of APP and its cleavage }\end{array}$ & Sathya et $\mathrm{al}^{\mathrm{l}^{3} 2}$ \\
\hline
\end{tabular}

AB: $\beta$-amyloid; GSK3: glycogen synthase kinase 3ß; EGCG: Epigallocatechin gallate; C. elegans: Caenorhabditis elegans; TTR: transthyretin; APP: amyloid precursor protein. 
Resveratrol intraperitoneal injection (10, 20 and $40 \mathrm{mg} / \mathrm{kg} /$ day) in Sprague-Dawley rats also improved cognitive impairment and attenuated LPS-induced neuroinflammation in rats, by inhibiting the generation of TNF, APP, cyclooxygenase (COX)-2 and NF- $\mathrm{\kappa B}$ phosphorylation in the hippocampus ${ }^{41}$.

In mouse neuroblastoma (N2a) cells incubated with $A \beta$, pretreatment with resveratrol $(5 \mu \mathrm{M})$ prevented the abnormal expression of peroxiredoxins and mitochondrial structural genes and preserved mitochondrial function, protecting cells against $A \beta$ toxicity ${ }^{42}$. Also in N2a cells, resveratrol $(0,2.5,5,10,25$ and $50 \mu \mathrm{M})$ significantly reduced formaldehyde-induced cytotoxicity and cellular apoptosis, and inhibited tau protein hyperphosphorylation in a dose-dependent manner ${ }^{24}$. Similar results were found in another experiment, in which resveratrol $(0,10,20$ and $40 \mu \mathrm{M})$ dose-dependently increased the viability of $\mathrm{A} \beta$-treated PC12 cells and stimulated HO-1 production. The cytoprotective mechanism was mediated by the PI3K/Akt/Nrf2 pathway ${ }^{43}$, which has also been found responsible for the neuroprotective effect of resveratrol, resulting in a decrease of $\operatorname{ROS}^{17}$.

Several studies have shown that the activation of AMPK (adenosine monophosphate-activated protein kinase) suppresses inflammation by inhibiting NF- $\kappa B$, preventing oxidative stress. Resveratrol is a potent activator of AMPK, thereby implicating another pathway through that its neuroprotective effects may be exerted ${ }^{3}$.

An experiment in human neural stem cells (hNSCs) demonstrated that $A \beta$-treated cells increase the expression of TNF and IL- $1 \beta$, thereby decreasing cell viability. In addition to inhibiting such deleterious effects, resveratrol $(10 \mu \mathrm{M})$ prevented the increase of NF- $\mathrm{KB}$ and normalized oxidative stress. These effects were attributed to the AMPK pathway3.

The antioxidant resveratrol effects were also verified by Rege et al. in an H19-7 neuronal cell line derived from rat hippocampus. Resveratrol $(10 \mu \mathrm{M})$ attenuated lipid peroxidation and upregulated antioxidant enzyme levels, such as catalase, superoxide dismutase (SOD), and glutathione reductase (GR). An interesting finding of this experiment was the increased levels of non-enzymatic antioxidants attributed to resveratrol, such as ascorbic acid, $\alpha$-tocopherol, and glutathione ${ }^{15}$.

The same study showed that resveratrol decreased the expression of insulin-degrading enzyme (IDE). Insulin regulates neuronal function after crossing the BBB, facilitating glucose uptake by neurons. Insulin resistance, which is a characteristic of type 2 diabetes mellitus, is an important risk factor for $\mathrm{AD}^{15}$.

Another association between glucose metabolism and $\mathrm{AD}$ is the presence of advanced glycation end products (AGEs) from the Maillard reaction between carbohydrates and proteins. Advanced glycation end products and their receptors (RAGEs) have been identified in neurons and hippocampus and have been associated with oxidative stress-induced neurotoxicity, as demonstrated by Ko et al., in which the administration of resveratrol (10 and $20 \mu \mathrm{M})$ reduced ROS production in cells treated with AGEs ${ }^{44}$.
In addition, RAGEs located at the BBB are the main gateway for $A \beta$ peptide transport to the brain. In female Wistar rats, resveratrol $(20,40$ and $80 \mathrm{mg} / \mathrm{kg} /$ day for 12 weeks $)$ protects $\mathrm{BBB}$ integrity by reducing RAGE expression in the hippocampus and inhibiting the expression of matrix metalloproteinase-9 (MMP-9), which is responsible for the degradation of junction proteins. It also promotes the expression of Claudine protein-5, which is related to the tight junctions that regulate BBB permeability ${ }^{45}$.

Plasma and CSF analyses in patients with confirmed AD showed that previous treatment with resveratrol (initial dose was $500 \mathrm{mg} /$ day and was increased every 13 weeks until a final dose of 1,000 mg twice a day) attenuated neuroinflammation, reduced proinflammatory markers, and decreased MMP-9 in the CSF. Decreased levels of MMP-9 suggest that treatment with resveratrol may reduce CNS permeability and limit the infiltration of leukocytes and other inflammatory agents into the brain, thus preserving the integrity of BBB. Resveratrol also attenuated the patients' cognitive and functional decline $e^{46}$.

\section{The Sirtuin 1 (SIRT1) pathway}

One of the possible mechanisms by which resveratrol mediates neuroprotection is through the activation of the sirtuin 1 (SIRT1) pathway, which in turn inhibits the activation of the NF- $\kappa B$ signaling pathway. Through suppression of this pathway, SIRT1 is also able to protect neurons against $A \beta$ toxicity ${ }^{36}$.

SIRT1 is one of a class of NAD+- dependent histone deacetylases that play an essential role in the cellular functioning regulation ${ }^{2,47}$, by the deacetylation of substrates important in neurodegenerative diseases ${ }^{48}$. Table 2 shows the resveratrol effects on the neuroinflammation and activation of SIRT1.

Resveratrol $(0,2.5,5,7.5,10$ and $15 \mu \mathrm{M})$ protected SK-N-BE neuroblastoma cells against induced oxidative stress and increased cell viability. However, when SIRT1 was up regulated with administration of sirtinol, antioxidant activity of resveratrol was suppressed ${ }^{47}$. In PC12 cells, resveratrol (12.5, 25, 50 and $100 \mu \mathrm{M})$ increased cell viability, reduced apoptosis, and attenuated $A \beta$-induced neurotoxicity. The peptide-induced suppression of SIRT1 activity was reversed by resveratrol, indicating that the protective effects are mediated by the sirtuin pathway'.

In addition to SIRT1, sirtuin 2 (SIRT2) was also observed to participate in the regulation of neuronal survival, albeit through more diverse mechanisms. Activation of SIRT1 and inhibition of SIRT2 (through the administration of resveratrol and AGK-2, respectively) reduced the activation of RA and consequent production of proinflammatory mediators, emphasizing the role of sirtuins and their modulatory substances in strategies for $\mathrm{AD}$ treatment ${ }^{49}$.

\section{Effects on cognitive aspects}

It has been shown that SIRT1 is essential for synaptic plasticity and cognitive functioning and can modulate learning and memory by regulating cAMP response element 
Table 2. Effects of resveratrol on neuroinflammation, neuroprotection, and SIRT1.

\begin{tabular}{|c|c|c|c|c|}
\hline Compound & Sample & Administration & Results & Reference \\
\hline $\begin{array}{l}\text { Resveratrol } \\
\text { and sirtinol }\end{array}$ & $\begin{array}{c}\text { SK-N-BE } \\
\text { neuroblastoma cells }\end{array}$ & $\begin{array}{l}\text { Added in medium }(0,2.5 \text {, } \\
5,7.5,10 \text { and } 15 \mu \mathrm{M})\end{array}$ & $\begin{array}{c}\text { Protected cells from oxidative stress induced } \\
\text { by } \mathrm{H}_{2} \mathrm{O}_{2} \text { and } 6-\mathrm{OHDA} \text {, increasing cell viability. } \\
\text { Sirtinol inhibited SIRT1 }\end{array}$ & Albani et al:47 \\
\hline Resveratrol & $\begin{array}{l}\text { Sprague-Dawley } \\
\text { rats }\end{array}$ & $\begin{array}{l}\text { Intraperitoneal injection } \\
(10,20 \text { and } 40 \mathrm{mg} / \mathrm{kg} / \text { day })\end{array}$ & $\begin{array}{l}\text { Improved cognitive impairment and attenuated } \\
\text { LPS-induced neuroinflammation in rats by } \\
\text { inhibiting the generation of TNF, APP, COX-2 and } \\
\text { NF-kB phosphorylation in the hippocampus }\end{array}$ & Gong et al..$^{41}$ \\
\hline Resveratrol & $\begin{array}{l}\text { Mouse } \\
\text { neuroblastoma } \\
\text { (N2a) cells }\end{array}$ & Added in medium $(5 \mu \mathrm{M})$ & $\begin{array}{l}\text { Prevented the abnormal expression of } \\
\text { peroxiredoxins and mitochondrial structural } \\
\text { genes and preserved mitochondrial function, } \\
\text { protecting cells against } A \beta \text { toxicity }\end{array}$ & Manczak et al. ${ }^{42}$ \\
\hline Resveratrol & $\begin{array}{l}\text { Sprague-Dawley } \\
\text { rats }\end{array}$ & $\begin{array}{l}\text { Injection of } 100 \mu \mathrm{m} / 5 \mu \mathrm{L} \\
\text { in the lateral ventricle } \\
\text { for seven days }\end{array}$ & $\begin{array}{l}\text { Reversed expression of iNOS, reduced amyloid } \\
\text { accumulation, prevented neuronal death, } \\
\text { increased HO-1 expression, suppressed } \\
\text { lipid peroxidation in hippocampus, } \\
\text { and improved spatial memory }\end{array}$ & Huang et al.39 \\
\hline
\end{tabular}

BV-2 microglial

Resveratrol cells and RAW 264.7

macrophages and

APP/PS1 mice

$\begin{array}{lcc}\text { Resveratrol } & \text { PC12 cells } & \begin{array}{c}\text { Added in medium } \\ (12.5,25,50 \text { and } 100 \mu \mathrm{M})\end{array} \\ \text { Resveratrol } & \begin{array}{c}\text { Sprague-Dawley's } \\ \text { astroglia cell } \\ \text { and AGK-2 }\end{array} & \begin{array}{c}\text { Added in medium } \\ (2,10 \text { and } 50 \mu \mathrm{M})\end{array} \\ & \text { culture } & \end{array}$

Added in medium and supplementation of 350 $\mathrm{mg} / \mathrm{kg} / \mathrm{day}$ for 15 weeks

Added in medium

Added in medium

Supplementation of

$\begin{array}{llc}\begin{array}{l}\text { Resveratrol } \\ \text { and LD55 }\end{array} & \text { A PPP/PS1 mice } & \begin{array}{c}\text { Supplementation of } \\ 100 \text { ppm for } 12 \text { months }\end{array}\end{array}$

SH-SY5Y
Resveratrol
neuroblastoma cells

$\begin{array}{cc}\text { Rat } \mathrm{H} 19-7 \\ \text { Trans-resveratrol } & \text { neuronal cell line }\end{array}$

Added in medium

$(10$ and $20 \mu \mathrm{M})$

Added in medium

$(10 \mu \mathrm{M})$

Added in medium

$(1,3,10$ or $30 \mu \mathrm{M})$

Resveratrol BV-2 microglial cells

$\begin{array}{ccc}\text { Resveratrol } & \text { Wistar female rats } & \begin{array}{c}20,40 \text { and } 80 \mathrm{mg} / \mathrm{kg} / \text { day } \\ \text { for } 12 \text { weeks }\end{array} \\ \text { Resveratrol } & \text { HEK-AbPP cells } & \begin{array}{c}\text { Added in medium } \\ (0.5 \mu \mathrm{M})\end{array}\end{array}$

$\begin{array}{lcc}\text { Resveratrol } & \begin{array}{c}\text { Human neural stem } \\ \text { cells }(\text { HhNSCs })\end{array} & \begin{array}{c}\text { Added in } \\ \text { medium }(10 \mu \mathrm{M})\end{array} \\ \text { Resveratrol } & \begin{array}{c}\text { Neuro-2a (N2a) } \\ \text { cell culture }\end{array} & \begin{array}{c}\text { Added in medium } \\ (0,2.5,5,10,25 \text { and } 50 \mu \mathrm{M})\end{array} \\ \text { Resveratrol } & \text { PC12 cell culture } & \begin{array}{c}\text { Added in medium } \\ (0,10,20 \text { and } 40 \mu \mathrm{M})\end{array}\end{array}$

Prior treatment with an initial dose of $500 \mathrm{mg} /$ day,

Resveratrol

CSF samples of AD humans

Rat astrocytes (RA)
and microglia N9
cell lines

Trans-resveratrol, piceatannol and trans-4hidroxistilbene ncreasing every 13 weeks
until completion with $1,000 \mathrm{mg}$ twice/day

Added in medium

$(5,12.5$, and $25 \mu \mathrm{M}$ in

RA cell line and 10, 20, and $40 \mu \mathrm{M}$ in $\mathrm{N} 9$ cell line)
Added in medium

(20 and $50 \mu \mathrm{M}$ )
Inhibited activation of NF- $\kappa \mathrm{B}$ and its target genes (TNF and IL-6) and prevented activation of $A \beta$-mediated microglia

Capiralla et $\mathrm{al}^{\cdot 3} 8$

Increased cell viability, reduced apoptosis, attenuated $A \beta$-induced neurotoxicity and regenerated SIRT1 activity

Feng et al 2 Resveratrol and AGK-2 reduced

astrocyte activation and pro-inflammatory Scuderi et al $\cdot{ }^{4} \mathrm{~g}$ mediator production

Resveratrol reduced microglia activation, mainly

in the hippocampus. LD55 had the same efficacy, Solberg et al. ${ }^{20}$ even without the hydroxyl group

Reduced ROS production stimulated by AGEs

Ko et $\mathrm{al}^{\cdot} \cdot 4$

Attenuated lipid peroxidation, regulated levels

of antioxidant enzymes and increased nonenzymatic antioxidants levels

Reduced ROS production and inhibited NO, TNF and IL-1 $\beta$ production

Rege et al. ${ }^{15}$

Reduced expression of AGEs and MMP-9, preserving BBB integrity

Yao et al:8

Ceased most of the neurotoxicity and pro-apoptotic effects on cells treated with $\gamma$-secretase inhibitor (LY450139)

Inhibited increase of TNF and IL-1 $\beta$ expression,

preventing reduction on cell viability, prevented

$\mathrm{NF}-\kappa \mathrm{B}$ increase, and normalized oxidative stress

Decreased cytotoxicity and cellular apoptosis

and inhibited tau hyperphosphorylation

Increased cell viability and stimulated $\mathrm{HO}-1$ production

Zhao et $a^{\cdot} \cdot 45$

Colin et al. ${ }^{40}$

Chiang et al.3

He et al.24

Hui et $\mathrm{al}^{\cdot}{ }^{3} 3$

Attenuated neuroinflammation, reduced proinflammatory markers and MMP-9 in the CSF, attenuated the cognitive and

Moussa et $\mathrm{al}^{\cdot} \cdot 4$ functional decline of individuals

Inhibited the release of inflammatory cytokines by inhibiting NF- $\kappa B$ signaling

Haifeng et al..$^{37}$
The stilbenoids inhibited $A \beta$-induced neurotoxicity, resulting in ROS decrease
Wen et al ${ }^{1} 7$

Aß: $\beta$-amyloid; H2O2: hydrogen peroxide; 6-OHDA: 6-hydroxydopamine; LPS: lipopolysaccharide; APP: amyloid precursor protein; COX-2: cyclooxygenase

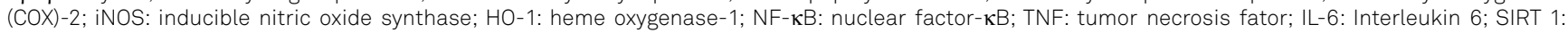
sirtuin 1; ROS: Reactive oxygen species; AGEs: advanced glycation end-products; NO: nitric oxide; IL-1 $\beta$ : Interleukin 1 $\beta$; MMP-9: matrix metalloproteinase-9; BBB: blood-brain barrier; AD: Alzheimer's disease; CSF: cerebrospinal fluid. 
binding protein (CREB) protein expression. It is noteworthy that levels of SIRT1 and CREB protein are significantly reduced in $\mathrm{AD}$ brains, and this reduction is strongly associated with $A \beta$ deposition in the cerebral cortex of these individuals. In light of this, the injection of resveratrol $(0.5,1.25$, $5,22$, and $44 \mu \mathrm{M})$ in Sprague-Dawley rats prevents memory damage and $A \beta$-induced learning and restores SIRT1 levels and CREB phosphorylation in the hippocampus of these animals ${ }^{50}$. Similarly, in another experiment, CREB levels were decreased by $\mathrm{A} \beta 42$ peptides, and the oral administration of 20 and $40 \mathrm{mg} / \mathrm{kg} /$ day of resveratrol for three days of resveratrol reversed the condition ${ }^{19}$.

In an animal model of $\mathrm{AD}, 100 \mathrm{mg} / \mathrm{kg}$ supplementation of resveratrol for 10 months protected against memory impairment, improved exploratory behavior, and reduced anxiety. Resveratrol also increased AMPK levels by stimulating SIRT1 and, consequently, CREB protein. The hippocampus is one of the areas selectively affected in $\mathrm{AD}$ and the deterioration of hippocampal circuits contributes significantly to some effects of the disease, such as memory loss. The positive action of resveratrol on spatial learning and memory of the mice was associated with an improvement in the functioning of hippocampal circuits ${ }^{18}$.

Also in an animal model of $\mathrm{AD}$, Porquet et al. observed that $1 \mathrm{~g} / \mathrm{kg} /$ day supplementation of resveratrol increased life expectancy, reduced cognitive impairment by preserving memory, and reduced amyloid deposition in the hippocampus, and tau protein levels in the cortex and hippocampus. In addition, resveratrol activated the AMPK and SIRT1 pathways ${ }^{48}$.
Similar results were found in another study, in which the $16 \mathrm{mg} / \mathrm{kg} /$ day supplementation of resveratrol prevented loss of short-term memory and decreased the amount and load of amyloid plaques in the hippocampus and cortex of the animals ${ }^{51}$. In addition, Wang et al. found that administration of 20 and $40 \mathrm{mg} / \mathrm{kg} /$ day of resveratrol in mice was also effective in reducing $A \beta$-induced memory and learning impairment and decreasing the expression of proinflammatory cytokines (IL-1 $\beta$ and IL-6) ${ }^{19}$. Also, the resveratrol injection $(4 \mathrm{mg} / \mathrm{kg}$ ) in mice reduced the decline of different memory types, such as working, nonspatial and locomotor functions, induced by LPS, and increased both neprilysin (NEP) and estradiol levels. In turn, estradiol also increased the NEP levels, which are responsible for decreasing $A \beta$ deposition ${ }^{52}$. The effects of resveratrol on cognitive aspects are summarized in Table 3.

\section{Autophagic mechanisms}

Among the mechanisms of neuronal protection, autophagy has been highlighted as a catabolic process related to the degradation and recycling of macromolecules and organelles ${ }^{10}$. There is strong evidence that, in the brain of $\mathrm{AD}$ patients, autophagic mechanisms are dysregulated and they participate in the intracellular degradation of $A \beta$ in both in vitro and in vivo models ${ }^{16}$. Mechanisms responsible for the clearance of $A \beta$ and tau proteins include the ubiquitin-proteasome system (UPS), the lysosomal autophagic system, and the actions of extracellular proteases ${ }^{18}$.

In order to determine the autophagy role in the anti-neurotoxic effect of resveratrol, $\mathrm{PC} 12$ cells were exposed to $\mathrm{A} \beta$

Table 3. Effects of resveratrol on cognitive aspects.

\begin{tabular}{|c|c|c|c|c|}
\hline Compound & Sample & Administration & Results & Reference \\
\hline Resveratrol & $\begin{array}{l}\text { SAMR } 1 \text { and } \\
\text { SAMP8 mice }\end{array}$ & $\begin{array}{l}\text { Supplementation } \\
\text { of } 1 \mathrm{~g} / \mathrm{kg} / \text { day } \\
\text { for seven months }\end{array}$ & $\begin{array}{l}\text { Increased life expectancy, reduced cognitive } \\
\text { impairment, amyloid deposition in the } \\
\text { hippocampus and tau levels in the cortex and } \\
\text { hippocampus, activated AMPK and SIRT1 }\end{array}$ & Porquet et al. ${ }^{48}$ \\
\hline Resveratrol & AßPP/PS1 mice & $\begin{array}{l}\text { Supplementation } \\
\text { of } 16 \mathrm{mg} / \mathrm{kg} / \text { day for } \\
10 \text { months }\end{array}$ & $\begin{array}{l}\text { Prevented short-term memory loss, reduced } \\
\text { the amount of amyloid plaques in the } \\
\text { hippocampus and cortex, increased levels of } \\
\text { mitochondrial complex IV }\end{array}$ & Porquet et al. ${ }^{51}$ \\
\hline Resveratrol & Mice & Injection (4 mg/kg) & $\begin{array}{c}\text { Reduced the decline in different memory } \\
\text { types (working, nonspatial, and locomotor } \\
\text { functions) induced by LPS, and increased } \\
\text { both NEP and estradiol levels, consequently } \\
\text { decreasing A } \beta \text { deposition }\end{array}$ & $\begin{array}{c}\text { El-Sayed } \\
\text { and Bayan }{ }^{52}\end{array}$ \\
\hline Resveratrol & AßPP/PS1 mice & $\begin{array}{l}\text { Oral administration } \\
\text { of } 20 \text { and } 40 \mathrm{mg} / \mathrm{kg} / \mathrm{day} \\
\text { for three weeks }\end{array}$ & $\begin{array}{c}\text { Reduced } A \beta \text {-induced impairment on memory } \\
\text { and learning, decreased IL-1 } \beta \text {, IL- } 6 \text { and pro- } \\
\text { apoptotic protein expression and reversed } \\
\text { A } \beta 42 \text {-induced decrease of CREB }\end{array}$ & Wang et al. ${ }^{19}$ \\
\hline Resveratrol & $\begin{array}{l}\text { Sprague-Dawley } \\
\text { rats }\end{array}$ & $\begin{array}{l}\text { Injection into the } \\
\text { hippocampus }(0.5,1.25 \text {, } \\
5,22 \text {, and } 44 \mu \mathrm{M})\end{array}$ & $\begin{array}{l}\text { Prevented memory and learning impairment } \\
\text { and restored the reduction of SIRT1 levels and } \\
\text { CREB phosphorylation. }\end{array}$ & Wang et al. ${ }^{50}$ \\
\hline Resveratrol & 3xTg-AD mice & $\begin{array}{l}\text { Supplementation } \\
\text { of } 100 \mathrm{mg} / \mathrm{kg} / \mathrm{day} \\
\text { for } 10 \text { months }\end{array}$ & $\begin{array}{l}\text { Improved memory and cognition and reduced } \\
\text { anxiety. Increased AMPK, SIRT1 and CREB }\end{array}$ & Corpas et al. ${ }^{18}$ \\
\hline
\end{tabular}

AB: $\beta$-amyloid; AMPK: adenosine monophosphate-activated protein kinase; SIRT 1: sirtuin 1; IL-1ß: Interleukin 1ß; IL-6: Interleukin 6; LPS: lipopolysaccharide; NEP: neprilysin; CREB: cAMP response element binding protein. 
and cell viability was reduced in a dose-dependent manner. Resveratrol $(20 \mu \mathrm{M})$ attenuated this effect and was also responsible for regulating the expression of LC3-II and p62 proteins, which are autophagy markers. The resveratrol induced autophagic mechanism and was dependent on SIRT ${ }^{10}$.

Mitophagy is a specific autophagy form, which plays an important role in the mitochondria control. The selective removal of dysfunctional mitochondria by mitophagy is an effective way of limiting neuronal oxidative damage. In PC12 cells, resveratrol $(1,3,10$ and $30 \mu \mathrm{M})$ promoted mitophagy in $\mathrm{A} \beta$-treated cells, in addition to reducing the oxidative state and attenuating peptide-induced apoptosis, indicating that resveratrol-induced mitophagy played a protective role against oxidative damage by removing dysfunctional mitochondria ${ }^{53}$.

The mammalian rapamycin target (mTOR) is a potent inhibitor of autophagy and is negatively regulated by AMPK, which in turn controls important mechanisms for protein degradation. Vingtdeux et al. showed that the anti-amyloidogenic resveratrol mechanism involves the activation of AMPK in different cell lines and in primary mouse neurons, a process that resulted in the inhibition of mTOR, initiation of autophagy, and lysosomal clearance of $A \beta^{16}$.

UPS is the primary mechanism that maintains the balance between synthesis and protein degradation and is related to several neuronal functions, such as memory and plasticity. Functional changes in this system have been associated with early changes in $\mathrm{AD}$. In mice, $100 \mathrm{mg} / \mathrm{kg} /$ day supplementation of resveratrol for 10 months decreased $A \beta$ and tau levels, by reducing BACE1 enzyme and increasing neprilysin (A $\beta$-degrading enzyme), in addition to normalizing ubiquitin levels ${ }^{18}$.

\section{Metal ions and ion channels}

Another risk factor in $\mathrm{AD}$ onset and development in the elderly is the accumulation of metals. The metal ion homeostasis imbalance in the brain may exacerbate the oxidative properties of $A \beta$ peptides and their toxicity through the production of ROS ${ }^{6}$. Recent evidence indicates that high concentrations of metal ions such as copper, zinc and iron can bind to $A \beta$ peptides, which promotes not only amyloid aggregation, but also accelerates ROS formation and cerebral oxidative stress ${ }^{54}$.

A study conducted by Granzotto and Zatta in human neuroblastoma cells exposed to $A \beta$, A $\beta$-metal complexes, or metal ions concluded that treatment with resveratrol resulted in a neuroprotective effect, reduced the toxicity induced by $\mathrm{A} \beta$-Iron and A $\beta$-Zinc complexes, and regulated levels of SOD antioxidant enzyme. Resveratrol concentration required to inhibit 50\% (IC50) of cell viability was found to be $100 \mu \mathrm{M}$. A concentration of $15 \mu \mathrm{M}$ was shown to be largely non-toxic ${ }^{6}$.

It was also shown that the association of $A \beta$ with aluminum had the most potent effect on reducing cell viability ${ }^{6}$. Aluminum acts as a neurotoxin capable of enhancing neuroinflammatory processes and, as studies have demonstrated, is associated with exacerbation of oxidative stress, amyloid deposition, and plaque formation in the brain. Both $A \beta$ peptides and aluminum are capable of potentiating the formation of ROS, leading to DNA damage ${ }^{36}$.

Zaky et al. demonstrated that oral administration of $0.5 \mathrm{mg} / \mathrm{kg}$ of resveratrol in Wistar rats for one month attenuated aluminum-induced neuroinflammation, inhibiting TNF, IL-6 and iNOS release in the animals' brains ${ }^{36}$.

Ion channels have become drug targets for neurodegenerative diseases treatment and voltage-gated potassium channels (VGPC), present in the hippocampus, and play a crucial role in neuronal activity. $\beta$-amyloid peptides can cause excitotoxicity in pyramidal neurons, as demonstrated by Yin et al., in which $A \beta$ treatment increased the excitability of these cells in the CA1 region of the rat hippocampus. Treatment with resveratrol $(10 \mu \mathrm{M})$ attenuated this effect by recovering the activity of two important VGPCs ${ }^{55}$.

\section{Perspectives}

The results from both in vitro and in vivo studies indicate that resveratrol is a promising and safe compound for use in the $\mathrm{AD}$ treatment ${ }^{26}$. However, as discussed by Moussa et al., one of the major impediments to current $\mathrm{AD}$ therapeutic approaches is the limited evidence demonstrating significant clinical benefits $^{46}$. There is a lack of phase 3 clinical trials that test the clinical benefits of resveratrol in $\mathrm{AD}$ as a primary outcome.

Resveratrol seems to exert beneficial effects on $\mathrm{AD}$ due to its diverse pharmacological properties. However, applicability for disease treatment is limited by factors such as low solubility, photosensitivity, short half-life and rapid metabolism and excretion, contributing to low bioavailability ${ }^{22}$. In addition, resveratrol is poorly hydrosoluble and chemically unstable and is degraded when exposed to high temperature, $\mathrm{pH}$ changes, ultraviolet radiation, and some enzymes ${ }^{25}$.

The BBB represents a significant obstacle to the entry of drugs into the CNS, restricting the pharmacological options for neurodegenerative diseases ${ }^{22}$. However, studies show that resveratrol is able to cross the $\mathrm{BBB}^{45}$ as discussed by Vingtdeux et al. and Capiralla et al., in which orally administered resveratrol in rats was able to reach the brain and reduce $A \beta$ levels and amyloid deposition in the cerebral cortex. This shows that resveratrol is not only bioavailable, but also bioactive ${ }^{16,38}$.

The complexity of $\mathrm{AD}$ and lack of scientific understanding regarding the onset and progression make the search for therapeutic strategies difficult ${ }^{13}$. Treatment with only either antioxidants or anti-inflammatory drugs has been shown ineffective in preventing $\mathrm{AD}$. Therefore, the development of multi-target drugs is an alternative approach ${ }^{23}$.

Authors of the studies reviewed herein seemingly agree that further research is needed to clarify the mechanisms by which resveratrol affects $\mathrm{AD}$ pathophysiology, and to demonstrate efficacy and safety in humans. Therefore, phase 3 clinical trials are required to test the clinical benefits of resveratrol. However, these studies provide an excellent foundation for future exploration. 
In addition to resveratrol, other polyphenols have gained attention for playing important roles in the pathophysiological mechanisms of $\mathrm{AD}$. Curcumin, isolated from the rhizome of Curcuma longa (turmeric), improved mitochondrial activity and cell viability in cells incubated with $A \beta(66.3 \mathrm{mM}$ final concentration) ${ }^{56}$, reduced Caveolin-1 (protein that participates in the cleavage of APP and the generation of A $\beta$ ) levels, potentially inactivating GSK- $3 \beta$ and inhibiting Tau hyperphosphorylation (5 $\mu \mathrm{M}$ in N2a/APP695swe cells and $1.0 \mathrm{~g} / \mathrm{kg}$ in APP/PS1 mice) ${ }^{57}$. In mice, curcumin suppressed glia activation and neuroinflammation, thereby improving induced tau/amyloid pathology and cognitive impairment $(4 \mathrm{~g} / \mathrm{kg})^{58}$. Epigallocatechin gallate (EGCG) polyphenol found in green tea reduced in vitro amyloid accumulation and improved cognitive decline in SAMP8 mice (intragastric administration of 5 and $15 \mathrm{mg} / \mathrm{kg})^{59}$, and suppressed the transcription and translation of BACE1. This attenuated A $\beta$ formation, which reduced pro-apoptotic protein expression, NF- $\kappa B$ activity and inhibited oxidative stress $(5-100 \mu \mathrm{M})^{60}$. EGCG also suppressed TNF, IL-6, IL-1 $\beta$ and iNOS expression, restored intracellular antioxidant levels, inhibited NF- $\kappa B$ activation and cytotoxicity (5 to $20 \mu \mathrm{M})^{61}$. Prolonged consumption of EGCG at relatively high doses $(15 \mathrm{mg} / \mathrm{kg})$ by SAMP8 mice improved animals' memory, reduced their $A \beta$ and BACE1 levels, prevented hyperphosphorylation of tau, and reversed the decreased synaptic protein marker ${ }^{62}$. Cocoa polyphenols have also been studied due to their possible neuroprotective effects. Cocoa extract was effective in reducing the oligomerization of $A \beta$ and protected against $A \beta$-induced long-term potentiation deficit ${ }^{63}$. Cocoa polyphenols resulted in antioxidant effect and neuroprotection by brain-derived neurotrophic factor (BDNF) activation ${ }^{64}$.

The potential role of other polyphenols in the pathophysiological aspects of $\mathrm{AD}$ is remarkable. Chan et al., who determined the relative potencies of nine food constituents in relation to $\mathrm{AD}$ including curcumin and EGCG, observed resveratrol to be a weak chelating agent, with very high concentrations required for $50 \%$ metal chelation. Resveratrol was also the least antioxidant compound and $100 \mu \mathrm{M}$ was required to inhibit $27 \%$ of the $A \beta$ fibrillar formation ${ }^{14}$. These findings further highlight the need of studies combining polyphenols as a multi-target strategy for the prevention or treatment of $\mathrm{AD}$.

\section{CONCLUSIONS}

Much effort has been employed in investigating the potential contribution of resveratrol to the treatment and attenuation of AD. Studies with varying scope and outcomes seemingly converge on the conclusion that this polyphenol provides a promising alternative therapeutic, capable of acting on various aspects of disease pathophysiology.

However, it is noteworthy that most of this research was conducted in cell culture or animal models, and there is a lack of human clinical studies that demonstrate the safety and efficacy of resveratrol for the treatment of $\mathrm{AD}$. The exact pathophysiology of $\mathrm{AD}$ is poorly understood, and there are no models that accurately portray the multifactoriality of the disease; these are obstacles that present important challenges for successful outcomes of research in this area.

Although the antioxidant and anti-inflammatory function of resveratrol has been widely described in the literature, its metabolism and structural characteristics present challenges for application in therapeutic settings. The action mechanisms have not been completely understood, and the optimal dose and route of administration in $\mathrm{AD}$ patients are unclear. In addition, there is no consensus on the therapeutic impact of resveratrol obtained through the diet, combined with other nutrients in the food matrix, compared to its action alone, either in the form of extracts or synthetic analogues.

In view of these findings, we conclude that, although resveratrol appears to mitigate some pathophysiological aspects of $\mathrm{AD}$, further studies are needed to prove the safety and efficacy of this compound in humans.

\section{References}

1. Cristòfol R, Porquet D, Corpas R, Coto-Montes A, Serret J, Camins A, et al. Neurons from senescence-accelerated SAMP8 mice are protected against frailty by the sirtuin 1 promoting agents melatonin and resveratrol: Melatonin and resveratrol protect SAMP8 neurons. J Pineal Res. 2012 Apr;52(3):271-81. https://doi.org/10.1111/j.1600079X.2011.00939.x

2. Feng X, Liang N, Zhu D, Gao Q, Peng L, Dong H, et al. Resveratrol Inhibits $\beta$-Amyloid-Induced Neuronal Apoptosis through Regulation of SIRT1-ROCK1 Signaling Pathway. PLoS One. 2013 Mar;8(3):e59888. https://doi.org/10.1371/journal.pone.005988

3. Chiang MC, Nicol CJ, Cheng YC. Resveratrol activation of AMPKdependent pathways is neuroprotective in human neural stem cells against amyloid- $\beta$-induced inflammation and oxidative stress. Neurochem Int. 2018 May;115:1-10. https://doi.org/10.1016/j. neuint.2017.10.002
4. Dong YT, Cao K, Tan LC, Wang XL, Qi XL, Xiao Y, et al. Stimulation of SIRT1 attenuates the level of oxidative stress in the brains of APP/PS1 double transgenic mice and in primary neurons exposed to oligomers of the amyloid- $\beta$ peptide. J Alzheimers Dis. 2018 Apr;63(1):283-301. https://doi.org/10.3233/JAD-171020

5. Zhang J, Feng X, Wu J, Xu H, Li G, Zhu D, et al. Neuroprotective effects of resveratrol on damages of mouse cortical neurons induced by $\beta$-amyloid through activation of SIRT1/Akt1 pathway: SIRT1/ Akt1 mediates neuroprotective effects of resveratrol. BioFactors. 2014 Mar/Apr;40(2):258-67. https://doi.org/10.1002/biof.1149

6. Granzotto A, Zatta P. Resveratrol acts not through anti-aggregative pathways but mainly via its scavenging properties against $A \beta$ and A $\beta$-metal complexes toxicity. PLoS One. 2011 Jun;6(6):e21565. https://doi.org/10.1371/journal.pone.0021565 
7. Karthick C, Periyasamy S, Jayachandran KS, Anusuyadevi M. Intrahippocampal administration of ibotenic acid induced Cholinergic Dysfunction via NR2A/NR2B expression: implications of resveratrol against Alzheimer Disease pathophysiology. Front Mol Neurosci. 2016 Apr;26(9):28. https://doi.org/10.3389/ fnmol.2016.00028

8. Yao Y, Li J, Niu Y, Yu JQ, Yan L, Miao ZH, et al. Resveratrol inhibits oligomeric A $\beta$-induced microglial activation via NADPH oxidase. Mol Med Rep. 2015 Aug;12(4):6133-9. https://doi.org/10.3892/mmr.2015.4199

9. Gupta R, Gupta LK, Mediratta PK, Bhattacharya SK. Effect of resveratrol on scopolamine-induced cognitive impairment in mice. Pharmacol Rep. 2012 Mar/Apr;64(2):438-44. https://doi.org/10.1016/ s1734-1140(12)70785-5

10. Deng H, Mi M. Resveratrol Attenuates Aß25-35 Caused Neurotoxicity by Inducing Autophagy Through the TyrRS-PARP1-SIRT1 Signaling Pathway. Neurochem Res. 2016 May;41(9):2367-79. https://doi. org/10.1007/s11064-016-1950-9

11. Turner RS, Thomas RG, Craft S, van Dyck CH, Mintzer J, Reynolds $\mathrm{BA}$, et al. A randomized, double-blind, placebo-controlled trial of resveratrol for Alzheimer disease. Neurology. 2015 Oct;85(16):138391. https://doi.org/10.1212/WNL.0000000000002035

12. Ge JF, Qiao JP, Qi CC, Wang CW, Zhou JN. The binding of resveratrol to monomer and fibril amyloid beta. Neurochem Int. 2012 Dec;61(7):1192-201. https://doi.org/10.1016/j.neuint.2012.08.012

13. Wang J, Bi W, Cheng A, Freire D, Vempati P, Zhao W, et al. Targeting multiple pathogenic mechanisms with polyphenols for the treatment of Alzheimer's disease-experimental approach and therapeutic implications. Front Aging Neurosci. 2014 Mar;6(42). https://doi. org/10.3389/fnagi.2014.00042

14. Chan S, Kantham S, M Rao V, Kumar Palanivelu M, L Pham H. Metal chelation, radical scavenging and inhibition of $A \beta 42$ fibrillation by food constituents in relation to Alzheimer's disease. Food Chem. 2016 May;199:185-94. https://doi.org/10.1016/j. foodchem.2015.11.118

15. Rege S, Geetha T, Broderick T, Babu J. Resveratrol protects $\beta$ amyloid induced oxidative damage and memory associated proteins in $\mathrm{H} 19-7$ hippocampal neuronal cells. Curr Alzheimer Res. 2015;12(2):147-56. https://doi.org/10.2174/1567205012666150204130009

16. Vingtdeux V, Giliberto L, Zhao H, Chandakkar P, Wu Q, Simon JE, et al. AMP-activated protein kinase signaling activation by resveratrol modulates amyloid- $\beta$ peptide metabolism. J Biol Chem 2010 Mar;285(12):9100-13. https://doi.org/10.1074/jbc.M109.060061

17. Wen H, Fu Z, Wei Y, Zhang X, Ma L, Gu L, et al. Antioxidant Activity and Neuroprotective Activity of Stilbenoids in Rat Primary Cortex Neurons via the PI3K/Akt Signalling Pathway. Molecules. 2018 Sep;23(9):2328. https://doi.org/10.3390/molecules23092328

18. Corpas R, Griñán-Ferré C, Rodríguez-Farré E, Pallàs M, Sanfeliu C. Resveratrol Induces Brain Resilience Against Alzheimer Neurodegeneration Through Proteostasis Enhancement. Mol Neurobiol. 2018 Jun;56(2):1502-16. https://doi.org/10.1007/ s12035-018-1157-y

19. Wang G, Chen L, Pan X, Chen J, Wang L, Wang W, et al. The effect of resveratrol on beta amyloid-induced memory impairment involves inhibition of phosphodiesterase-4 related signaling. Oncotarget. 2016 Mar;7(14);17380-92. https://doi.org/10.18632/oncotarget.8041

20. Solberg NO, Chamberlin R, Vigil JR, Deck LM, Heidrich JE, Brown DC, et al. Optical and SPION-enhanced MR imaging shows that trans-stilbene inhibitors of NF- $\kappa B$ concomitantly lower Alzheimer's Disease plaque formation and microglial activation in A $\beta P P / P S-1$ transgenic mouse brain. J Alzheimers Dis. 2014 Mar;40(1):191-212. https://doi.org/10.3233/JAD-131031

21. Tafoya MA, Madi S, Sillerud LO. Superparamagnetic nanoparticleenhanced MRI of Alzheimer's disease plaques and activated microglia in 3Xtransgenic mouse brains: Contrast optimization: Optimizing MRI of 3X Tg AD Mouse Brains. J Magn Reson Imaging. 2017 Aug;46(2):574-88. https://doi.org/10.1002/jmri.25563
22. Frozza RL, Bernardi A, Hoppe JB, Meneghetti AB, Matté A, Battastini AM, et al. Neuroprotective effects of resveratrol against $A \beta$ administration in rats are improved by lipid-core nanocapsules. Mol Neurobiol. 2013 Jan;47(3):1066-80. https://doi.org/10.1007/ s12035-013-8401-2

23. Vion E, Page G, Bourdeaud E, Paccalin M, Guillard J, Rioux Bilan A. Trans $\varepsilon$-viniferin is an amyloid- $\beta$ disaggregating and anti-inflammatory drug in a mouse primary cellular model of Alzheimer's disease. Mol Cell Neurosci. 2018 Apr;88:1-6. https://doi. org/10.1016/j.mcn.2017.12.003

24. He X, Li Z, Rizak JD, Wu S, Wang Z, He R, et al. Resveratrol attenuates formaldehyde induced hyperphosphorylation of tau protein and cytotoxicity in N2a cells. Front Neurosci. 2017 Jan;31(10):598. https://doi.org/10.3389/fnins.2016.00598

25. Loureiro JA, Andrade S, Duarte A, Neves A, Queiroz J, Nunes C, et al. Resveratrol and grape extract-loaded solid lipid nanoparticles for the treatment of Alzheimer's disease. Molecules. 2017 Feb;22(2):277. https://doi.org/10.3390/molecules22020277

26. Feng Y, Wang X, Yang S, Wang Y, Zhang X, Du X, et al. Resveratrol inhibits beta-amyloid oligomeric cytotoxicity but does not prevent oligomer formation. Neurotoxicology. 2009 Nov;30(6):986-95. https:// doi.org/10.1016/j.neuro.2009.08.013

27. Ladiwala ARA, Lin JC, Bale SS, Marcelino-Cruz AM, Bhattacharya M, Dordick JS, et al. Resveratrol Selectively Remodels Soluble Oligomers and Fibrils of Amyloid A $\beta$ into Off-pathway Conformers. J Biol Chem. 2010 Jul;285(31):24228-37. https://doi.org/10.1074/jbc. M110.133108

28. Rushworth JV, Griffiths HH, Watt NT, Hooper NM. Prion proteinmediated toxicity of amyloid- $\beta$ oligomers requires lipid rafts and the transmembrane LRP1. J Biol Chem. 2013 Mar;288(13):8935-51. https://doi.org/10.1074/jbc.M112.400358

29. Fu Z, Aucoin D, Ahmed M, Ziliox M, Van Nostrand WE, Smith SO. Capping of $A \beta 42$ Oligomers by Small Molecule Inhibitors. Biochemistry. 2014 Nov;53(50):7893-903. https://doi.org/10.1021/bi500910b

30. Hung VWS, Cheng XR, Li N, Veloso AJ, Kerman K. Electrochemical Detection of Amyloid-Beta Aggregation in the Presence of Resveratrol.J Electrochem Soc. 2013 Apr;160(7):G3097-101. https:// doi.org/10.1149/2.014307jes

31. Regitz C, Fitzenberger E, Mahn FL, Dußling LM, Wenzel U. Resveratrol reduces amyloid-beta (A $\beta 1-42)$-induced paralysis through targeting proteostasis in an Alzheimer model of Caenorhabditis elegans. Eur J Nutr. 2016 Apr;55(2):741-7. https:// doi.org/10.1007/s00394-015-0894-1

32. Sathya M, Moorthi P, Premkumar P, Kandasamy M, Jayachandran KS, Anusuyadevi M. Resveratrol Intervenes Cholesterol- and IsoprenoidMediated Amyloidogenic Processing of A PPP in Familial Alzheimer's Disease. J Alzheimers Dis. 2017 Sep;60(s1):S3-23. https://doi. org/10.3233/JAD-161034

33. Karuppagounder SS, Pinto JT, Xu H, Chen H-L, Beal MF, Gibson GE. Dietary supplementation with resveratrol reduces plaque pathology in a transgenic model of Alzheimer's disease. Neurochem Int. 2009 Feb;54(2):111-8. https://doi.org/10.1016/j.neuint.2008.10.008

34. Varamini B, Sikalidis AK, Bradford KL. Resveratrol increases cerebral glycogen synthase kinase phosphorylation as well as protein levels of drebrin and transthyretin in mice: an exploratory study. Int J Food Sci Nutr. 2014;65(1):89-96. https://doi.org/10.3109/ 09637486.2013 .832171

35. Santos LM, Rodrigues D, Alemi M, Silva SC, Ribeiro CA, Cardoso I. Resveratrol administration increases transthyretin protein levels, ameliorating $A D$ features: the importance of transthyretin tetrameric stability. Mol Med. 2016 Jun;22(1):597-607. https://doi.org/10.2119/ molmed.2016.00124

36. Zaky A, Mohammad B, Moftah M, Kandeel KM, Bassiouny AR. Apurinic/apyrimidinic endonuclease 1 is a key modulator of aluminum-induced neuroinflammation. BMC Neurosci. 2013 Mar;14(1):26. https://doi.org/10.1186/1471-2202-14-26 
37. Haifeng Z, Qian W, Xuejiao C, Xuemin L, Na L. Inhibitive effect of resveratrol on the inflammation in cultured astrocytes and microglia induced by Aß1-42. Neuroscience 2018 May;379:390-404. https:// doi.org/10.1016/j.neuroscience.2018.03.047

38. Capiralla H, Vingtdeux V, Zhao H, Sankowski R, Al-Abed Y, Davies P, et al. Resveratrol mitigates lipopolysaccharide- and $A \beta$-mediated microglial inflammation by inhibiting the TLR4/NF- $\mathrm{BB} / \mathrm{STAT}$ signaling cascade. J Neurochem. 2012 Feb;120(3):461-72. https://doi. org/10.1111/j.1471-4159.2011.07594.x

39. Huang TC, Lu KT, Wo YYP, Wu YJ, Yang YL. Resveratrol Protects Rats from $A \beta$-induced Neurotoxicity by the Reduction of iNOS Expression and Lipid Peroxidation. Musaro A, organizador. PLoS One 2011;6(12):e29102. https://doi.org/10.1371/journal.pone.0029102

40. Colin J, Allouche A, Chauveau F, Corbier C, Pauron-Gregory L, Lanhers M-C, et al. Improved neuroprotection provided by drug combination in neurons exposed to cell-derived soluble amyloid- $\beta$ peptide. J Alzheimers Dis. 2016 May;52(3):975-87. https://doi. org/10.3233/JAD-151110

41. Gong Q, Li F, Jin F, Chan N. Resveratrol Attenuates Neuroinflammation-mediated Cognitive Deficits in Rats. J Health Sci. 2010;56(6):655-63. https://doi.org/https://doi.org/10.1248/ jhs. 56.655

42. Manczak M, Mao P, Calkins MJ, Cornea A, Reddy AP, Murphy MP, et al. Mitochondria-targeted antioxidants protect against amyloid- $\beta$ toxicity in Alzheimer's disease neurons. J Alzheimer Dis. 2010 Jun;20(s2):S609-31. https://doi.org/10.3233/JAD-2010-100564

43. Hui Y, Chengyong T, Cheng L, Haixia H, Yuanda Z, Weihua Y. Resveratrol attenuates the cytotoxicity induced by amyloid- $\beta 1-42$ in PC12 cells by upregulating heme oxygenase-1 via the PI3K/Akt/ Nrf2 pathway. Neurochem Res. 2018 Oct;43(2):297-305. https://doi. org/10.1007/s11064-017-2421-7

44. Ko SY, Ko HA, Chu KH, Shieh TM, Chi TC, Chen HI, et al. The possible mechanism of advanced glycation end products (AGEs) for Alzheimer's disease. PLoS One. 2015 Nov;10(11):e0143345. https:// doi.org/10.1371/journal.pone.0143345

45. Zhao HF, Li N, Wang Q, Cheng XJ, Li XM, Liu TT. Resveratrol decreases the insoluble $A \beta 1-42$ level in hippocampus and protects the integrity of the blood-brain barrier in AD rats. Neuroscience. 2015 Dec;310:641-9. https://doi.org/10.1016/j.neuroscience.2015.10.006

46. Moussa C, Hebron M, Huang X, Ahn J, Rissman RA, Aisen PS, et al. Resveratrol regulates neuro-inflammation and induces adaptive immunity in Alzheimer's disease. J Neuroinflammation. 2017 Jan;14(1):1. https://doi.org/10.1186/s12974-016-0779-0

47. Albani D, Polito L, Batelli S, De Mauro S, Fracasso C, Martelli G, et al. The SIRT1 activator resveratrol protects SK-N-BE cells from oxidative stress and against toxicity caused by $\alpha$-synuclein or amyloid- $\beta$ (1-42) peptide. J Neurochem. 2009 Sep;110(5):1445-56. https://doi.org/10.1111/j.1471-4159.2009.06228.x

48. Porquet D, Casadesús G, Bayod S, Vicente A, Canudas AM, Vilaplana J, et al. Dietary resveratrol prevents Alzheimer's markers and increases life span in SAMP8. AGE. 2013 Nov;35(5):1851-65. https://doi.org/10.1007/s11357-012-9489-4

49. Scuderi C, Stecca C, Bronzuoli MR, Rotili D, Valente S, Mai A, et al. Sirtuin modulators control reactive gliosis in an in vitro model of Alzheimer's disease. Front Pharmacol. 2014 May;13(5)89. https://doi. org/10.3389/fphar.2014.00089

50. Wang R, Zhang Y, Li J, Zhang C. Resveratrol ameliorates spatial learning memory impairment induced by $A \beta 1-42$ in rats. Neuroscience. 2017 Mar;344:39-47. https://doi.org/10.1016/j. neuroscience.2016.08.051

51. Porquet D, Griñán-Ferré C, Ferrer I, Camins A, Sanfeliu C, del Valle J, et al. Neuroprotective Role of Trans-Resveratrol in a Murine Model of
Familial Alzheimer's Disease. J Alzheimers Dis. 2014;42(4):1209-20. https://doi.org/10.3233/JAD-140444

52. El-Sayed NS, Bayan Y. Possible role of resveratrol targeting estradiol and neprilysin pathways in lipopolysaccharide model of Alzheimer disease. Adv Exp Med Biol. 2015 Oct;822:107-18. https://doi. org/10.1007/978-3-319-08927-0_12

53. Wang H, Jiang T, Li W, Gao N, Zhang T. Resveratrol attenuates oxidative damage through activating mitophagy in an in vitro model of Alzheimer's disease. Toxicol Lett. 2018 Jan;282:100-8. https://doi. org/10.1016/j.toxlet.2017.10.021

54. Yang L, Wang W, Chen J, Wang N, Zheng G. A comparative study of resveratrol and resveratrol-functional selenium nanoparticles: Inhibiting amyloid $\beta$ aggregation and reactive oxygen species formation properties. J Biomed Mater Res A. 2018 Dec;106(12):303441. https://doi.org/10.1002/jbm.a.36493

55. Yin $\mathrm{H}$, Wang $\mathrm{H}$, Zhang $\mathrm{H}$, Gao N, Zhang T, Yang Z. Resveratrol attenuates $A \beta$-induced early hippocampal neuron excitability impairment via recovery of function of potassium channels. Neurotox Res. 2017 Oct;32(3):311-24. https://doi.org/10.1007/s12640-017-9726-9

56. Reddy PH, Manczak M, Yin X, Grady MC, Mitchell A, Kandimalla R, et al. Protective effects of a natural product, curcumin, against amyloid $\beta$ induced mitochondrial and synaptic toxicities in Alzheimer's disease. J Investig Med. 2016;64(8):1220-34. https://doi. org/10.1136/jim-2016-000240

57. Sun J, Zhang X, Wang C, Teng Z, Li Y. Curcumin decreases hyperphosphorylation of tau by down-regulating caveolin-1/GSK-3 $\beta$ in N2a/APP695swe cells and APP/PS1 double transgenic Alzheimer's disease mice. Am J Chin Med. 2017 Nov;45(8):1667-82. https://doi. org/10.1142/S0192415X17500902

58. Sundaram JR, Poore CP, Sulaimee NHB, Pareek T, Cheong WF, Wenk MR, et al. Curcumin ameliorates neuroinflammation, neurodegeneration, and memory deficits in p25 transgenic mouse model that bears hallmarks of Alzheimer's disease. J Alzheimers Dis. 2017 Nov;60(4):1429-42. https://doi.org/10.3233/JAD-170093

59. Chang X, Rong C, Chen Y, Yang C, Hu Q, Mo Y, et al.

(-)-Epigallocatechin-3-gallate attenuates cognitive deterioration in Alzheimer's disease model mice by upregulating neprilysin expression. Exp Cell Res. 2015 May;334(1):136-45. https://doi. org/10.1016/j.yexcr.2015.04.004

60. Zhang ZX, Li YB, Zhao RP. Epigallocatechin gallate attenuates $\beta$-amyloid generation and oxidative stress involvement of PPAR $\gamma$ in N2a/APP695 cells. Neurochem Res. 2017 Feb;42(2):468-80. https:// doi.org/10.1007/s11064-016-2093-8

61. Cheng-Chung Wei J, Huang HC, Chen WJ, Huang CN, Peng CH, Lin CL. Epigallocatechin gallate attenuates amyloid $\beta$-induced inflammation and neurotoxicity in EOC 13.31 microglia. Eur J Pharmacol. 2016 Jan;770:16-24. https://doi.org/10.1016/j.ejphar.2015.11.048

62. Guo Y, Zhao Y, Nan Y, Wang X, Chen Y, Wang S. (-)-Epigallocatechin-3gallate ameliorates memory impairment and rescues the abnormal synaptic protein levels in the frontal cortex and hippocampus in a mouse model of Alzheimer's disease. Neuroreport. 2017 Jul;28(10):590-7. https://doi.org/10.1097/WNR.0000000000000803

63. Wang J, Varghese M, Ono K, Yamada M, Levine S, Tzavaras N, et al. Cocoa Extracts Reduce Oligomerization of Amyloid- $\beta$ : Implications for Cognitive Improvement in Alzheimer's Disease. J Alzheimers Dis. 2014 Jun;41(2):643-50. https://doi.org/10.3233/JAD-132231

64. Cimini A, Gentile R, D’Angelo B, Benedetti E, Cristiano L, Avantaggiati $M L$, et al. Cocoa powder triggers neuroprotective and preventive effects in a human Alzheimer's disease model by modulating BDNF signaling pathway: cocoa for Alzheimer's disease protection. J Cell Biochem. 2013 Mar;114(10):2209-20. https://doi. org/10.1002/jcb. 24548 